\title{
Peanut Smut: From an Emerging Disease to an Actual Threat to Argentine Peanut Production
}

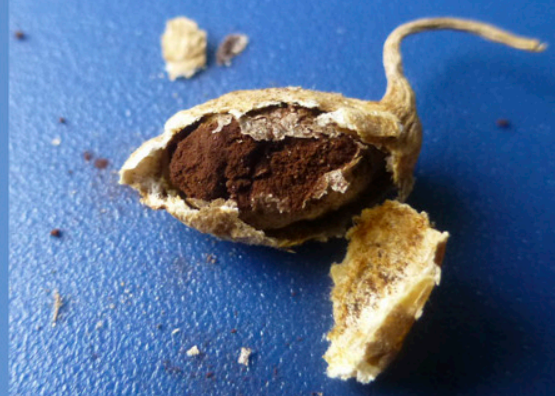

\author{
Alejandro Mario Rago \\ Instituto de Patología Vegetal; CIAP - INTA, Córdoba, Argentina, Facultad de Agronomía y Veterinaria, \\ UNRC, Córdoba, Argentina
}

Luis Ignacio Cazón, Juan Andrés Paredes, Juan Pablo Edwards Molina, and Erica Cinthia Conforto

Instituto de Patología Vegetal; CIAP - INTA, Córdoba, Argentina

Universidade de São Paulo/ESALQ - Departamento de Fitopatologia e Nematologia, Piracicaba, SP - Brasil

\section{Eduardo Matías Bisonard}

Centro de Investigaciones Agropecuarias; INTA, Córdoba, Argentina

Claudio Oddino

Facultad de Agronomía y Veterinaria, UNRC, Río Cuarto, Córdoba, Argentina

\begin{abstract}
The center of origin of peanut is located in South America, specifically in southeastern Bolivia and northwestern Argentina, where its parental species are found in wild habits (Fernández et al. 2006) (Fig. 1). In 1753, the botanist Linnaeus classified the cultivated species of peanut as Arachis hypogaea L. in two subspecies, hypogaea and fatstigiata (Krapovickas and Gregory 1994). A. hypogaea belongs to the family Leguminosae, subfamily Papilionoidea, genus Arachis (Lavia 1998). Peanut is an annual plant that grows best during the summer, germinating during spring or early summer and maturing by autumn of the same year. The growth habit of peanut is described as bunch, decumbent, or runner. Bunch types have an upright growth habit with flowering on the main stem and lateral branches. Runner types are considered to have a prostrate growth habit and do not flower on the main stem and decumbent varieties have an intermediate growth habit between a runner and bunch. The first records of cultivated peanut came from Argentina in 1872, in which an area of 2,388 ha was sown by the indigenous people of the country's northern regions (Fernández et al. 2006). More than $92 \%$ of Argentine peanut production and processing is located in the center of the country, mainly in the province of Córdoba (Bolsa de Cereales de Córdoba 2015) (Fig. 1). More than 12,000 jobs are directly or indirectly related to peanut production in Córdoba, and it is a significant contribution to the local economy (Cámara Argentina del Maní 2013). In 2014/2015, peanut was cultivated over 345,000 ha, producing a total of 1.12 million MT of peanut and an average yield of 3.48 MT/ha (Bolsa de Cereales de Córdoba 2015).
\end{abstract}

Corresponding author: Alejandro Mario Rago;

E-mail: rago.alejandro@inta.gob.ar

Accepted for publication 22 November 2016.

(C) 2017 The American Phytopathological Society
Even though Argentina is only the seventh largest producer of peanut in the world ( $2 \%$ of global production), it is the leading exporter of edible grain and crushed (e.g., flour, butter, and oil) peanut products worldwide (Fernandez et al. 2006; Fiant et al. 2013). More than $80 \%$ of Argentine production is exported to the European Union (mainly the Netherlands, Germany, England, Spain, Italy, Greece, and France), and other countries such as the United States, Canada, China, and India. All of this shows that the peanut industry is not only important to Argentina, but also to the world peanut market.

Manufactured products such as butter and oil were the main focus of the Argentine industry for many years; however, a shift to edible peanut started during the early 1980s. New cultivars were adapted for this purpose, passing from bunch type cultivars to runner types (with a longer maturity varieties), and the prevailing climatic conditions were conducive for the development of soilborne fungal diseases, such as sclerotinia blight and stem rot (Marinelli et al. 2006). This situation became worse due to the lack of adequate crop rotation programs, the improper use of fungicides (e.g., timing and active ingredients), and the use of fungicide seed treatments that were ineffective for managing these soilborne diseases. Peanut production was moved to more southern areas of Cordoba in the early 1990s to avoid the consequences of production issues in the northern region (March and Marinelli 2005). During this migration process, a new disease emerged in commercial plots: peanut smut caused by Thecaphora frezii (Fig. 2). Peanut smut was first detected in the northern peanut producing areas in Córdoba Province, and then established on the central region where the main grain processing industries are located. Currently, the prevalence is $100 \%$ in Argentinian peanut area. This finding showed evidence that pathogens could also migrate along with peanut production activities and contaminate soil of new production areas.

T. frezii was first reported in 1962 by Carranza and Lindquist in wild peanut samples from Aquidauana, Matto Grosso do Sul, Brazil (Carranza and Lindquist 1962) (Fig. 1). They classified the fungus based on disease symptoms and morphology of teliospores, but could 
not complete Koch's postulates since artificial inoculations were not possible. In Argentina, T. frezii was first detected in 1995 by Marinelli et al. (1995) in commercial crops of peanuts from the central-northern area of Córdoba Province: Pampayasta $\left(32^{\circ} 15^{\prime} 07^{\prime \prime} \mathrm{S}\right.$, $\left.63^{\circ} 39^{\prime} 20^{\prime \prime} \mathrm{W}\right)$, Villa Ascasubi $\left(32^{\circ} 10^{\prime} 00^{\prime \prime} \mathrm{S}, 63^{\circ} 53^{\prime} 00^{\prime \prime} \mathrm{W}\right)$, and Ticino $\left(32^{\circ} 41^{\prime} 25^{\prime \prime} \mathrm{S}, 63^{\circ} 23^{\prime} 14^{\prime \prime} \mathrm{W}\right)$. The most affected peanut varieties were Colorado Irradiado INTA and Florunner. Later Astiz Gassó and

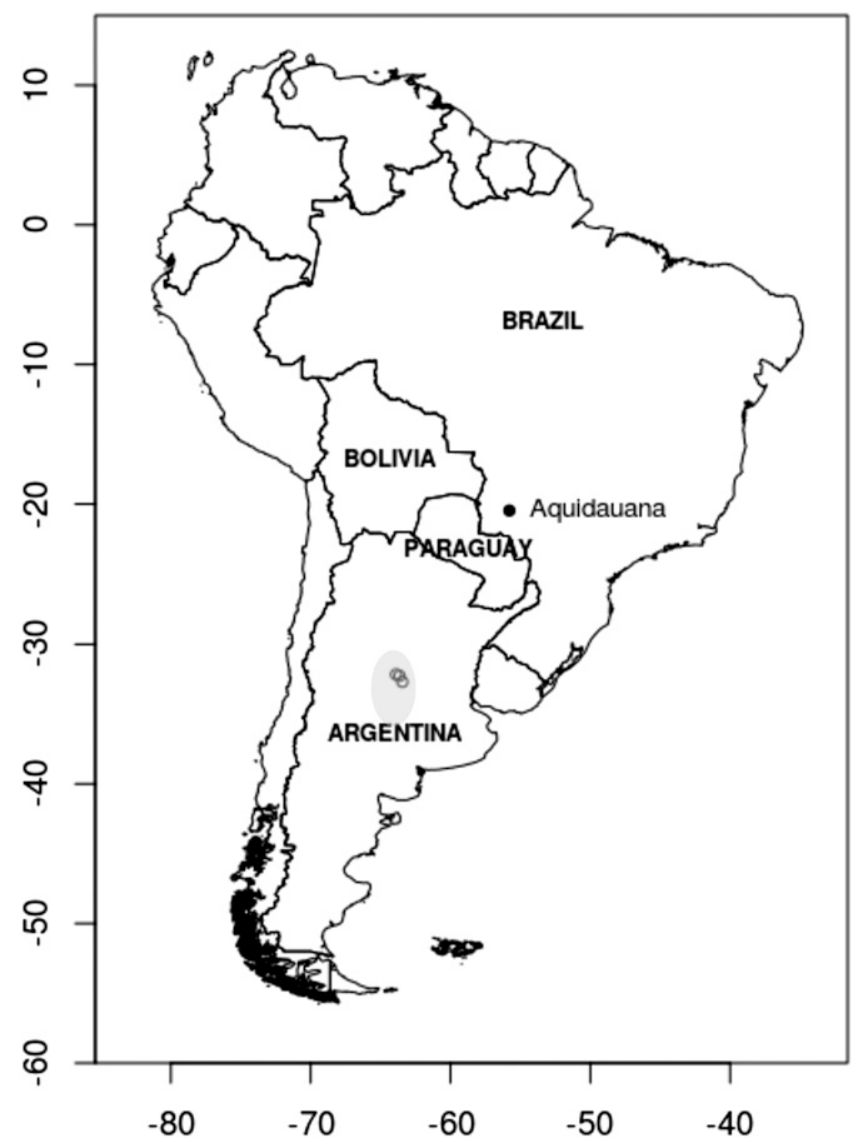

Fig. 1. Map of South America indicating the countries of center of origin of peanut. Filled point indicates the city of first report of Thecaphora frezii in wild peanut species (Aquidauana, Matto Grosso do Sul, Brazil). Empty points indicate the cities of first report of $T$. frezii in cultivated peanut (Córdoba Province, Argentina). Gray shaded area: current main production and processing area of peanut (Córdoba Province, Argentina).

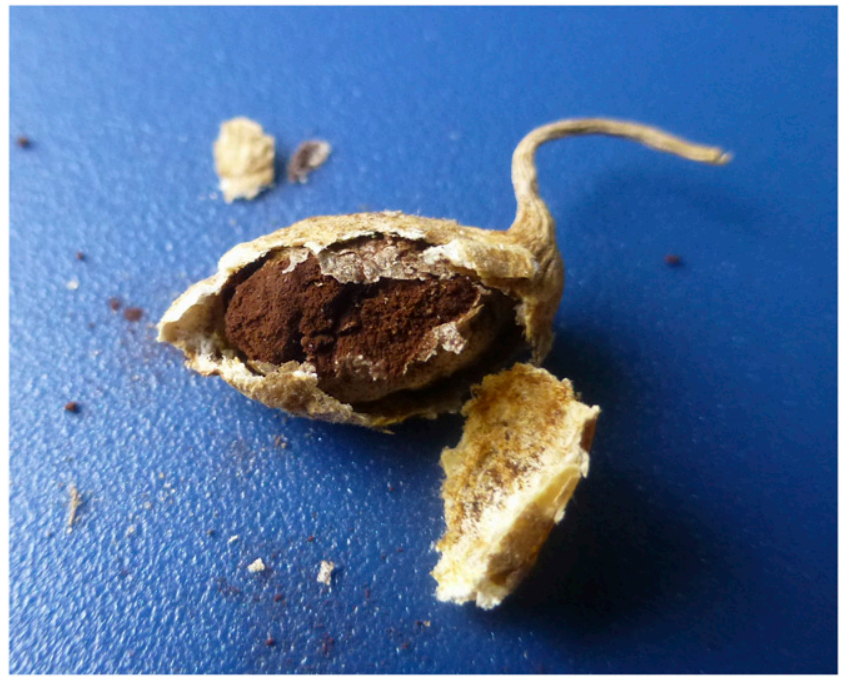

Fig. 2. Wild peanut pod totally damaged by smut (mass of teliospores replacing the grain tissue).
Marinelli $(2003,2013)$ succeeded in isolating $T$. frezii from peanut pods and study its infection process. They used leaf and fruit extracts with the addition of PDA medium (39 g/liter). The colonies were circular-radial, flat, grayish-brown, and had a growth rate of $5.3 \mathrm{~mm} /$ day, incubated at $25 \pm 1^{\circ} \mathrm{C}$ in darkness (Fig. 3). Since its first report, peanut smut incidence and intensity has gradually increased, to finally being found in all production fields in the 2011/2012 growing season (Bonessi et al. 2011; Cazzola et al. 2012). During the last 10 years, this disease has caused significant decreases in yield production in Argentina, resulting in $51 \%$ losses in some locations (Bonessi et al. 2011; Cazzola et al. 2012; March and Marinelli 2005; Oddino et al. 2010). Currently, Argentina is the only country that has reported peanut smut in commercial crops. Both Bolivia and Brazil, however, have only reported cases of smut in wild peanuts (Carranza and Lindquist 1962; Fávero 2004; Soave et al. 2014).

\section{Taxonomy}

T. frezii is in the class Ustilaginomycetes, family Glomosporiaceae, and in a newly recognized genus Thecaphora (Marinelli et al. 2010). Conforto et al. (2012, 2013) confirmed the original classification with molecular techniques. They used the universal primers NL1/NL4 (O'Donnell 1993) to amplify by PCR the D1/D2 region of the large (28S) rDNA subunit of four $T$. frezii isolates collected from different areas of the production region. They sequenced the obtained fragments $(650 \mathrm{pb})$ and compared them to the remaining sequences of the genus Thecaphora available in GenBank. The phylogenetic analysis showed $100 \%$ identity among sequences of T. frezii, $95.9 \%$ with T. oxalidis and $95.3 \%$ with T. solani (Fig. 4).

\section{Pathogen Life Cycle}

T. frezii produces teliospores, which are thick walled structures that enable the fungus to overwinter in soil and crop residue. Teliospores can survive in a metabolic dormant state in the soil without the presence of live hosts. When peanut pegs penetrate the soil, their exudates disrupt telial dormancy, which promotes spore germination and initiates local infections (Astiz Gassó and Marinelli 2003; Marinelli et al. 2008). According to Marraro Acuña et al. (2013), infection can occur during the peanut pegging process. The process of teliospore germination includes the formation of a probasidium, followed by a basidium that forms basidiospores through meiosis. When basidiospores germinate, compatible haploid germ tubes fuse and produce a dikaryotic mycelium, which is responsible for the infection process. The dikaryotic mycelium can penetrate the peanut

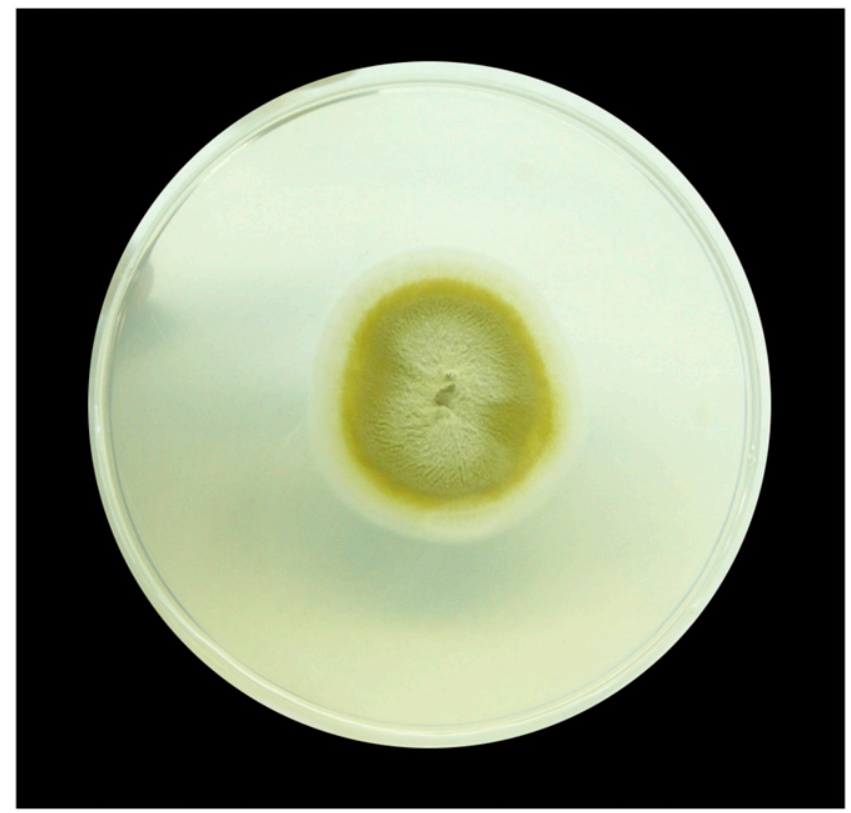

Fig. 3. Thecaphora frezii mycelial growth 7 days after being plated on potato dextrose agar medium (39 g/liter). 
gynophore in the soil, colonize the tissues, and replace the cells with reddish-brown teliospores (Astiz Gassó and Marinelli 2013; Astiz Gassó et al. 2011; Marinelli et al. 2010) (Fig. 5 and 7). Smut spores are brown, 20 to $40 \mu \mathrm{m}$ in size, and have an echinulate surface (Marraro Acuña et al. 2013) (Fig. 6). During harvest, these teliospores are dispersed by wind to adjacent fields (Fig. 8). Long distance dispersion is attributed to infested machinery and infected seeds. Infested machinery can carry teliospores from one infected field to another located in other province or bordering country. During shelling, teliospores can infest kernels externally or in small lesions that are not detected in the seed selection process (Marinelli et al. 2008) (Fig. 9).

\section{Teliospore Detection}

Early detection and estimation of the amount of teliospores of T. frezii, both in soil and seeds, is crucial to manage peanut smut. Oddino et al. (2010) reported that high levels of teliospores in the soil at planting can result in high smut incidence at harvest. They evaluated peanut smut in highly infested soil (4,000 teliospores/g of soil) obtained from $50 \%$ of affected pods. Another critical step to avoid the spread of the pathogen in fields is detecting teliospores in seeds. Since Argentina is the only country in South America that has reported this disease, the export of pathogen-free products is required to avoid penalties and trade barriers from other peanut-producing countries, hence the importance of implementing effective peanut smut management strategies that can minimize yield losses that can threaten the economy of the region, heavily affecting the entire peanut industry and production (Cámara Argentina del Maní, 2013; Marraro Acuña and Haro 2011; Marraro Acuña et al. 2009).

The simplest technique for teliospore detection and quantification in soil and seeds is to use an optical microscope, which should be available in every plant pathology laboratory. Marinelli et al. (2008) detected teliospores from a soil sample infected with $T$. frezzi by suspending the spores in distilled water, then quantifying them using a hemocytometer under the microscope. Marraro Acuña et al. (2012) also employed this technique to detect spores in peanut seeds.

A more sophisticated tool to identify the presence of $T$. frezii in soil or seeds is PCR. This technique has the advantage of being highly specific, sensitive, and independent of environmental conditions (Murashige and Skoog 1962). Cazón et al. (2014) described this protocol, which begins with washing off a kernel sample with distilled water, separating supernatant water from kernels, and extracting fungal DNA from the obtained pellet. PCR amplification is then

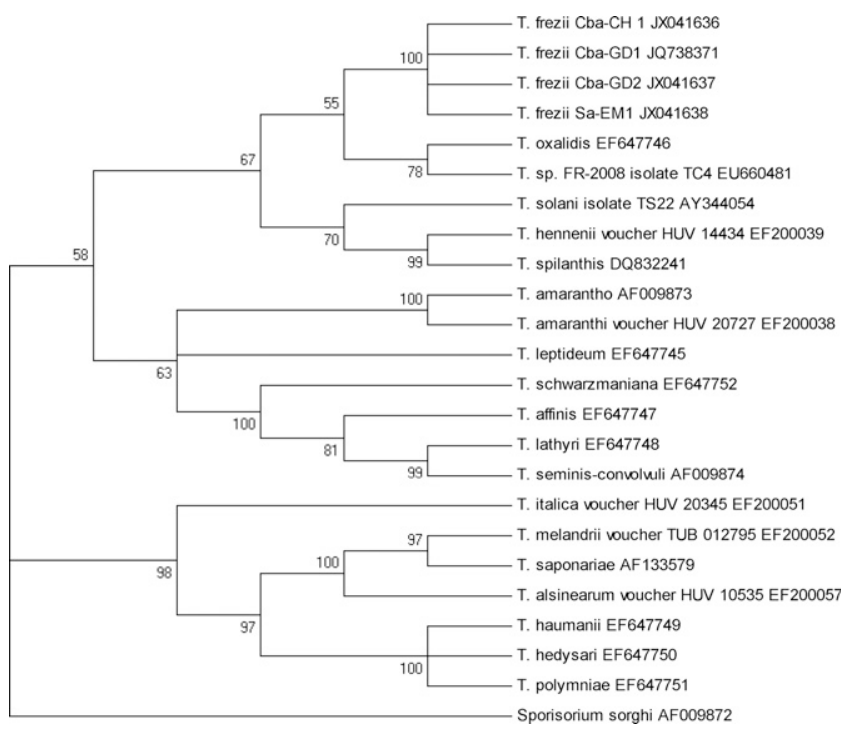

Fig. 4. Phylogenetic tree constructed with the NJ method based on partial sequence data of the large ribosomal subunit (D1/D2) of sequences of Thecaphora including new sequences of four different specimens of Thecaphora frezii from Argentina. A sequence of Sporisorium sorghi is used as outgroup. Bootstrap values higher than 50 are indicated (Conforto et al. 2013). performed using TF-2F/TF-2R primers, specifically designed for T. frezii. This method is highly sensitive, and can detect the presence of 10 teliospores $\left(10^{-4} \mathrm{pg}\right.$ DNA) from a sample of 400 kernels. Its specificity is achieved by using primers that do not hybridize with the DNA of other seedborne pathogens, such as Sclerotinia minor, $S$. sclerotiorum, Sclerotium rolfsii, or Fusarium solani (Cazón 2015). These primers can be adapted for teliospore quantification using real time PCR, with a detection sensitivity of two teliospores in a sample of 400 seeds (Cazón et al. 2016b).

\section{Disease Assessment}

The disease assessment performed when a given field is to be harvested in mature pods (R8). Only in this phenological state it is possible to estimate the severity of the disease in samples within a given field. In immature pods, infection is visible, but it is difficult to estimate the severity. Incidence (proportion of infected pods out of a total sample) and severity (proportion of damaged pod tissue) are estimated to quantify disease intensity in affected fields. Disease severity can be estimated using a diagrammatic scale representing five different severity levels, which was proposed by Astiz Gasso et al. (2008). Ordinal levels of 0: healthy pods; 1 : normal pod with a small sorus in single kernel; 2: deformed or normal pod with half of the kernels affected; 3 : deformed pod and a completely smutted kernel; and 4: deformed pod, two completely smutted kernels, can be observed in Figure 9. Combining both parameters, incidence and severity, it is possible calculate "intensity" (Paredes et al. 2014).

\section{Yield Losses}

Paredes et al. (2016) assessed peanut smut in 40 fields from the main peanut growing region of Córdoba and reported yield loss of 27,419 MT (US\$14,151,800), representing 3.15\% of the total production. In some fields, yield losses of $35 \%$ were observed. Results showed a significant linear relationship between estimated yield losses and disease intensity. Capello and Dignani (2015) affirm that the

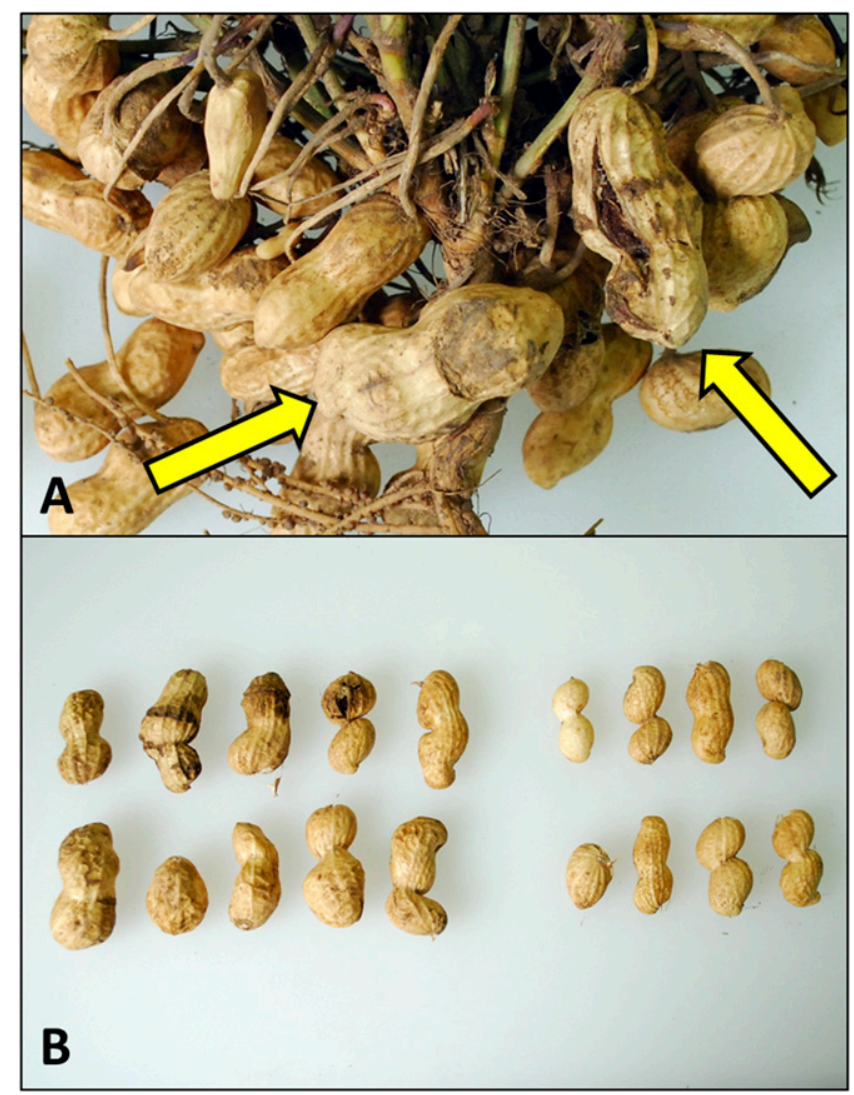

Fig. 5. Peanut pods affected by smut. A, Peanut plant with hypertrophied pods due to smut. B, Comparison between affected pods (left) and healthy pods (right). 
estimated losses in fields with low inoculum density is erratic, whereas the correlation was high between losses and the number of teliospores/g of soil in fields with high inoculum density. They reported that peanut smut incidence above $14 \%$ can be considered as a damage threshold and estimated that a $1 \%$ increase in incidence can correspond to a $1.2 \%$ decrease in yield.

\section{Peanut Smut Management}

Peanut smut is considered a monocyclic disease since there is no secondary inoculum produced during the growing season, and polyetic since annual inoculum accumulation affects subsequent seasons.
Therefore, the intensity of an epidemic is correlated with the initial amount of inoculum produced in the preceding growing seasons. It has been reported that $T$. frezii teliospore amount increases in the soil due to the following factors: 1) closeness to peanut processing factories; 2) number of years of peanut cultivation in the region; and 3) cropping pattern with back-to-back peanuts have higher smut severity then rotations with other crops. Paredes et al. (2016) surveyed peanut smut producing areas in Córdoba. They reported that disease intensity decreases southward. This gradient is because the new production areas are there, away from processing plants and with a much shorter history of peanut crop than in the north. It is

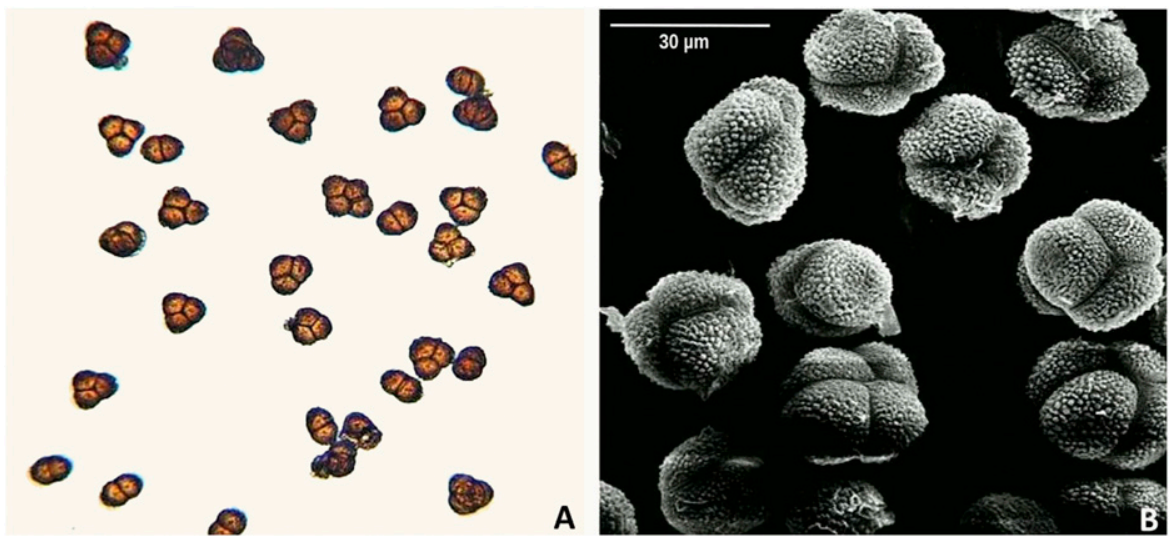

Fig. 6. Teliospores of Thecaphora frezii. A, Teliospores observed under light microscope at 10x. B, Scanning electron micrographs of multicellular teliospores.

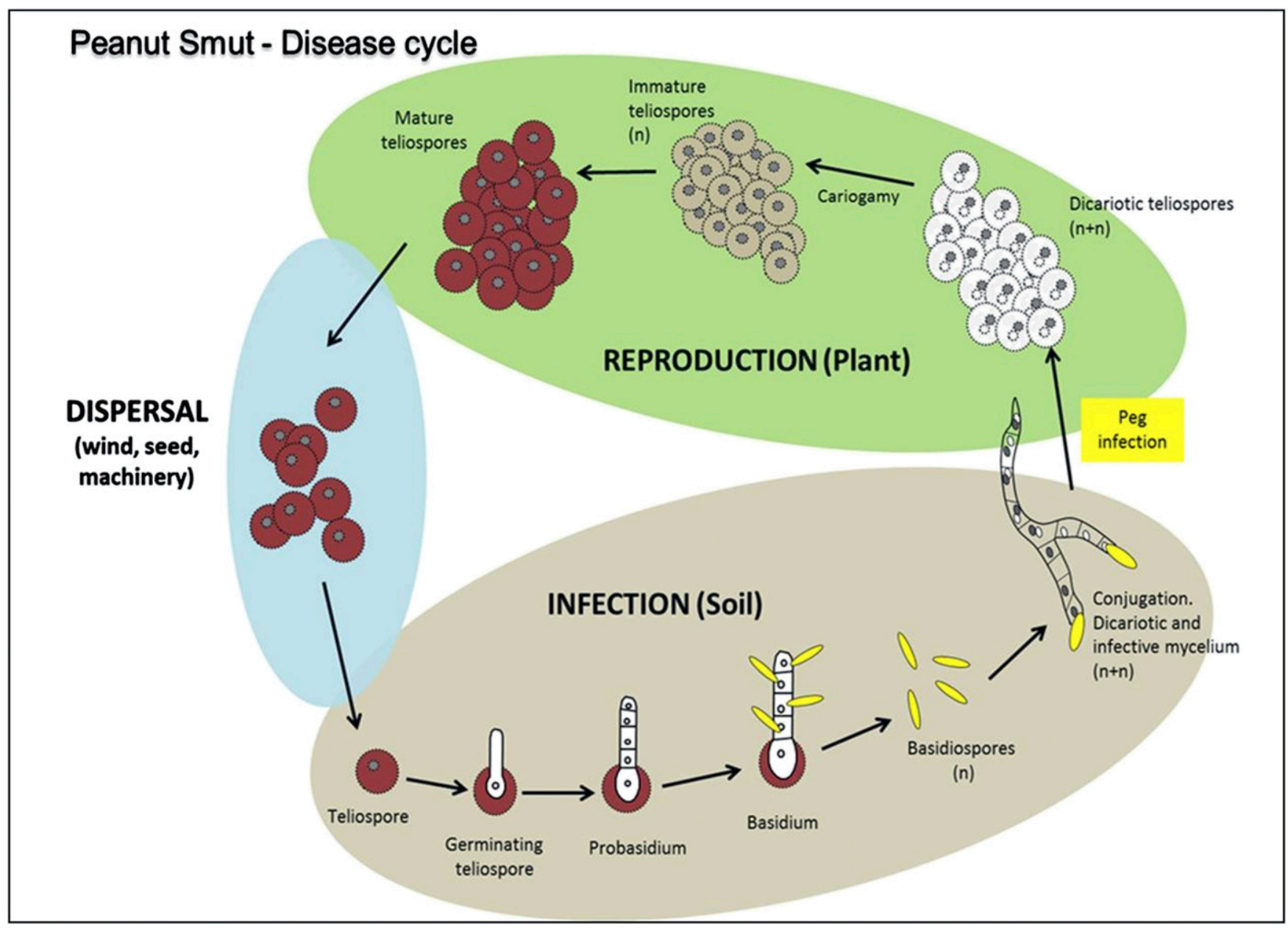

Fig. 7. Peanut smut disease cycle. 


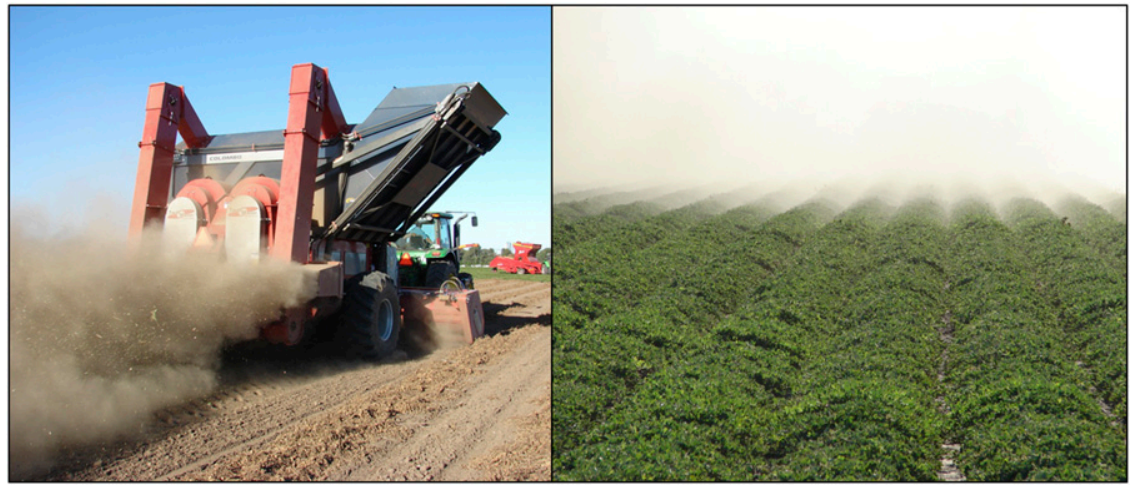

Fig. 8. Dust accumulated during peanut harvest (images provided by Rodolfo Bongiovanni).

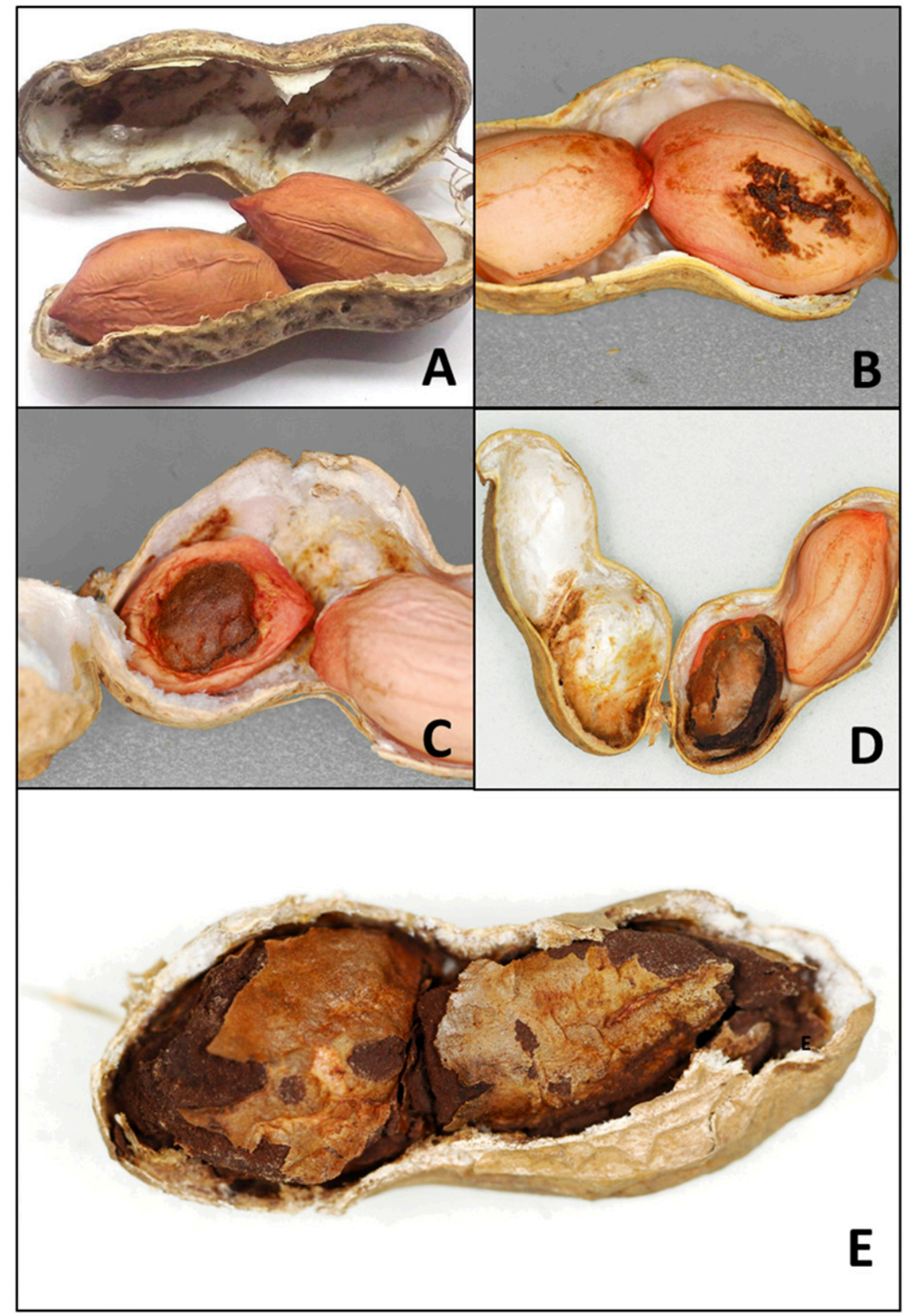

Fig. 9. Peanut smut severity scale. A, level 0. B, level 1. C, level 2. D, level 3. E, level 4.

404 Plant Disease /Vol. 101 No. 3 
important that management strategies in this region are implemented correctly to prevent an increase of inoculum in the soil. In the northern production areas, where soil infestation levels are high, it is important to use resistant varieties, supplemented with technological strategies to maintain resistance.

Cultural practices and biological control. Since peanut smut is a monocyclic, polyetic disease, management tactics should be focused on the reduction of initial inoculum. Crop rotation schemes of more than 3 years without peanuts showed low $T$. frezii teliospore density in soil, resulting in reduced levels of smut incidence and severity at crop maturity (Fundación Maní Argentino 2010). Capello and Dignani (2015) affirm that an incidence of $14 \%$ is a threshold for economic damage. In addition, peanut crops preceded by corn exhibited lower incidence of peanut smut than those preceded by soybean (Marraro Acuña and Haro 2011).

Other practices are improved by various authors for disease management. Spinazzé and Marraro Acuña (2010) and Cignetti et al. (2010b) concluded that burying teliospores using deep tillage (15 to $20 \mathrm{~cm}$ deep) reduces disease incidence, since peanut pods develop at a planting depth between 5 and $7 \mathrm{~cm}$. However, T. frezii has been shown to survive in the soil for more than 4 years (Cazón et al. 2016a), which indicates that deep tillage cannot completely remove teliospores. Therefore, in addition to tillage, other, more conservative soil practices are encouraged to help manage this disease.

Although the initial report of peanut smut was in wild peanut in Brazil, soil conditions and characteristics in the productive system prevented the disease in commercial peanut. In contrast to Argentina, Brazilian peanut areas have soils with low $\mathrm{pH}$. Moreover, their rotation scheme is longer ( 5 or 6 years with sugar cane before returning to peanuts), so the conditions of organic matter and microflora in the soil differ from the conditions of Argentine soil. Considering the complex life cycle of $T$. frezii within the soil prior to infection, any practice or technique that modifies soil chemical/physical properties will also disrupt the infection sequence. Bonessi et al. (2011) evaluated the effect of amendments such as gypsum $\left(\mathrm{CaSO}_{4}\right)$ and dolomite as an effective disease management practice. They observed that gypsum application can contribute to a partial reduction of peanut smut intensity; however, those factors were not clear and are still undetermined. Kearney et al. (2015) and Morla et al. (2015) assessed phosphite-containing products. They provided a $16 \%$ reduction in peanut smut intensity without affecting yields. Using biological control, the results are comparable. Pastor et al. (2015) and Ganuza et al. (2016) used a bioformulation based on Trichoderma harzianum, obtaining a control efficiency of $24 \%$ in incidence and $25 \%$ in severity. While each of these proposed management practices can offer some level of disease reduction, further studies are needed to improve peanut growers' knowledge and understanding of this disease as well as to implement integrated management practices that can result in more economic benefit for their efforts.

Crop protection fungicides. Growers use fungicide seed treatments with polymers to protect against pathogens that cause preand post-emergence damping-off. $T$. frezii, however, can still infect the pegs in the soil, even 40 days post-planting when seed treatments have lost their protective effects. For this reason, seed treatment with fungicides is not effective for peanut smut. Despite this, fungicides have been studied in recent years. Astiz Gassó and Wojszko (2011) performed an in vitro efficiency test for the fungicide mixture carboxin + metalaxyl + thiophanate methyl + captan (at $50+25+3.35+74 \mathrm{~g} / 100 \mathrm{~kg}$ of seed), which inhibited $70 \%$ of $T$. frezii mycelium development. In field trials with foliar spray of fungicides, control of peanut smut was highly variable (Cazón et al. 2013; Paredes et al. 2015a). Low reduction in disease severity may be attributed to the difficulty of reaching target tissue (i.e., flower peg) where infection of $T$. frezii occurs (Astiz Gassó et al. 2008; Marinelli et al. 2008, 2010). Paredes et al. (2015d, 2016) observed that soil-directed fungicide applications were more effective than leaf applications at controlling peanut smut. Soil spray applications might be done at night when the peanut leaves fold up and the soil surface is easily reached (Augusto et al. 2010a, b). In trials, fungicide applications to the soil using strobilurin/triazole mixtures like picoxystrobin + cyproconazole provided control efficiencies of 41 to $47 \%$ at a rate of 900 or $1,000 \mathrm{~cm}^{3} /$ ha in two applications in R2 (beginning peg) (Boote 1982) and 10 days after (Cazón et al. 2013; Paredes et al. 2014, 2015a). Paredes et al. (2014) also evaluated an experimental application of granulate fungicide with a slow release into the soil solution for longer protection during crop pegging. This alternative method provided a control efficiency of $42 \%$ reduction of peg damage severity using a formulation of picoxystrobin + cyproconazole, which can be applied at flowering. Similar results were observed with two sequential sprayings of the same active ingredients in commercial mixtures (Paredes et al. 2015a). In recent control efficiency studies, fungicides from the carboxamides group such as solatenol, penthiopyrad, isopyrazam, and fluxapyroxad were evaluated in reducing peg severity and results showed that efficiency range of from 18.5 to $52.1 \%$ (Paredes et al. 2015c). Control by fungicides is an alternative to peanut smut management, but results often vary widely. Control efficiencies close to 40 to $50 \%$ for this pathosystem is an acceptable value, so when accompanied by efficient molecules, correct dose, and good timing and application technologies, chemical control could contribute to integrated disease management, especially in areas with high levels of disease.

Host resistance. Despite having a limited number of registered cultivars exhibiting some level of tolerance to peanut smut (e.g., Pepe Asem INTA and Manigran with 30\% incidence reduction), $100 \%$ of cultivars widely planted are susceptible, which has allowed $T$. frezii to quickly spread throughout the growing region of Córdoba (Cignetti et al. 2010a). Therefore, an economical and effective addition to integrated pest management programs will be the use of resistant cultivars. Farías et al. (2011) evaluated the response of high-oleic cultivars to peanut smut and concluded that the cultivar Pepe ASEMINTA had $34 \%$ disease incidence versus $71 \%$ of the reference susceptible cultivar Colorado Irradiado-INTA. Wild species, such as A. correntina and A. valida, were found to have resistance to $T$. frezii (Astiz Gassó et al. 2011). M. Zuza et al. (unpublished) found tolerance in a commercial cultivar Mapu and in a precommercial breeding line from the National University of Río Cuarto, Córdoba. Among the tools used to facilitate the transfer of resistance there are the molecular methods. Faustinelli et al. (2015) found molecular markers associated with tolerance to peanut smut. Incorporating resistance genes currently found in commercial lines, precommercial lines, and in wild relatives will be of great value and this process can be done with the aid of marker assisted selection.

There are many factors that make genetic resistance the main tool for integrated management. First, high levels of infestation in the soils of the northern Córdoba peanut growing area could disable fields for peanut growth. Only resistance varieties can provide acceptable yield and prevent inoculum multiplication. Also, there is no commercial fungicide and application technology that provides high disease control. The best control efficiencies obtained with commercial fungicides reach $60 \%$ in highly infested batches. Those chemical strategies will be used with new varieties to keep resistance over time. There are cultivars highly tolerant to peanut smut in the final stages of evaluation. This material would also be useful to prevent the spread of the pathogen to new areas of production.

Another aspect that must be studied is to quantify the genetic variability and recombination potential of $T$. frezii. There is an emerging concern that $T$. frezii has high genetic variability, which would complicate durable resistance. It is why the study and development of new cultivars must be continuous.

Integrated management strategies. Based on the current understanding of the disease cycle of peanut smut and effectiveness of various techniques described above, the following disease management tactics are strongly recommended for growers in order to minimize potential crop losses:

- Use pathogen-free seed.

- Plant peanuts in fields that have no history of peanut smut and/or a low inoculum density of $T$. frezii teliospores.

- The fields chosen to cultivate peanut are not to be close to peanut processing factories. 
- Implement a 3-year crop rotation without peanuts.

- Spray fungicide mixtures including strobilurins and triazoles such as azoxistrobin and cyproconazole at the beginning of crop pegging and 7 days after, directed to the ground, and when possible, spray fungicides at night.

Disease management programs must take into consideration the easy spread of the inoculum over short distances. All above recommended practices will only be effective if they are implemented by all growers in an entire peanut area (regional management). Management of peanut smut can only be successful through the collaboration of all those involved in Argentinian peanut production systems. One batch of heavily infected (3,000 teliospores/g of soil) can contaminate the neighbor fields, so diligence and support among producers is critical to controlling this devastating disease.

\section{Conclusions and Perspectives}

Peanut smut is currently the most economically important peanut disease in Argentina. Following its first report in 1995, the disease is now present across the whole growing region in Argentina (approximately $345,000 \mathrm{ha}$ ). The spread of this fungus through seeds, wind, and agricultural machinery went unnoticed for many years, partly because there are no symptoms in the aerial part of the plant. In the mid-1990s, there was an increase in the scale of peanut production in Argentina. This event favored large companies that were able to afford large-scale, modern processing techniques. Many small and medium sized growers (planting $<200 \mathrm{ha}$ ) that used to harvest their own seeds were removed from the production system. Big growers produced and processed peanuts on a larger scale, which included both healthy and diseased fields. This approach favored seed contamination and spread of the pathogen. Additionally, new cultivars were favored that were high yielding but highly susceptible, which also contributed to disease increase. The challenge of breeding programs is to incorporate resistance genes into popular commercial cultivars in order to reduce teliospore production and delay the spread of smut into new planting areas. Molecular tools for identifying resistance QTLs are being developed, and hopefully they will be available for precision breeding programs soon. In order to protect against the future breakdown of resistance, it is critical that other regional management programs are in place. Additional research must determine the most effective fungicides with the most suitable application technologies that reach the target plant tissue.

Although the first reports of the disease were done in wild peanuts from Brazil, the disease is not present in commercial crops in that country. This may be because its production system uses rotation schemes including sugar cane, a semiperennial crop ( $>3$ years) in soils with very different characteristics to those of Argentina, particularly its $\mathrm{pH}$. Since Argentina is a major worldwide exporter of peanuts, it is of global consequence that peanut smut is better understood and effectively managed both to preserve the market and prevent further spread of disease.

\section{Acknowledgments}

We wish to thank Fundación Maní for providing resources for many research experiments cited in this review, and Karasi Mills and Jorge David Salgado (The Ohio State University) for critically reviewing the manuscript prior to submission.

\section{Literature Cited}

Astiz Gassó, M., Leis, R., and Marinelli, A. 2008. Evaluación de incidencia y severidad del carbón de maní (Thecaphora frezii) en infecciones artificiales, sobre cultivares comerciales de maní. $1^{\circ}$ Congreso Argentino de Fitopatología.

Astiz Gassó, M., and Marinelli, A. 2013. Pages 62-63 in: Biología de la germinación de Thecaphora frezii in vitro. $28^{\circ}$ Jornada Nacional de Maní. General Cabrera, Córdoba, Argentina.

Astiz Gassó, M., and Wojszko, A. 2011. Pages 60-62 in: Evaluación in vitro de fungicidas curasemillas para el control químico del carbón del maní. $26^{\circ}$ Jornada Nacional del Maní. General Cabrera, Córdoba, Argentina.

Astiz Gassó, M. M., Leis, R., and Marinelli, A. D. 2011. Evaluación de tolerancia de germoplasma de maní (Arachis spp.) para el manejo del carbón (Thecaphora frezii). Pages 58-59 in: $26^{\circ}$ Jornada Nacional del Maní. General Cabrera, Córdoba, Argentina.
Astiz Gassó, M. M., and Marinelli, A. 2003. Cultivo in vitro de Thecaphora frezii (ustilaginales), carbón de maní (Arachis hypogea). Page 256 in: $29^{\circ}$ Jornadas Argentinas de Botánica \& $15^{\circ}$ Reunión Anual de la Sociedad Botánica de Chile.

Augusto, J., Brenneman, T. B., Culbreath, A. K., and Sumner, P. 2010a. Night spraying peanut fungicides I. Extended fungicide residual and integrated disease management. Plant Dis. 94:676-682.

Augusto, J., Brenneman, T. B., Culbreath, A. K., and Sumner, P. 2010b. Night spraying peanut fungicides II. Application timings and spray deposition in the lower canopy. Plant Dis. 94:683-689.

Bolsa de Cereales de Córdoba y Cámara de Cereales y Afines de Córdoba. 2015 Informe especial no. 69, Campaña 2014/2015: Producción final de maní Córdoba, Argentina.

Bonessi, F., Rago, A. M., Marinelli, A. D., March, G. J., Cazón, L. I., García, J., and Oddino, C. M. 2011. Efecto de la fertilización sobre la intensidad del carbón del maní. Pages 63-64 in: 26 ${ }^{\circ}$ Jornada Nacional del Maní. General Cabrera, Córdoba, Argentina.

Boote, K. J. 1982. Growth stages of peanut. Peanut Sci. 9:35-40.

Cámara Argentina del Maní. 2013. Outlook del Cluster Manisero Argentino. Córdoba, Argentina.

Capello, G., and Dignani, D. 2015. Control quimico del carbon del maní y cuantificacion de la perdida de rendimiento en grano utilizando como medida valores de incidencia. Pages 75-76 in: $30^{\circ}$ Jornada Nacional del Maní. General Cabrera, Córdoba, Argentina.

Carranza, J., and Lindquist, J. 1962. Thecaphora frezii, parasita de Arachis sp. Bol Soc. Argent. Bot. 10:11-18.

Cazón, L. I. 2015. Detección molecular de Thecaphora frezii Carranza \& Lindquist en semillas de maní Arachis hypogaea. Tesis de Maestría. Universidad Nacional de Córdoba. Facultad de Ciencias Agropecuarias, Córdoba, Argentina.

Cazón, L. I., Bisonard, E. M., Conforto, C., March, G., and Rago, A. 2013. Estrategias para el manejo del carbón del maní. Pages 28-30 in: $28^{\circ}$ Jornada Nacional del Maní. General Cabrera, Córdoba, Argentina.

Cazón, L. I., Conforto, C., Paredes, J. A., Bisonard, E. M., and Rago, A. M. 2014 Sensibilidad y especificidad de la técnica de PCR en la detección de teliosporas de Thecaphora frezii en semillas de maní. Pages 40-42 in: $29^{\circ}$ Jornada Nacional de Maní. General Cabrera, Córdoba, Argentina.

Cazón, L. I., Paredes, J. A., Bisonard, E. M., and Rago, A. M. 2016a. Capacidad de infección de Thecaphora frezii en el tiempo. 31 ${ }^{\circ}$ Jornada Nacional de Maní. 22 de Septiembre. General Cabrera, Córdoba, Argentina.

Cazón, L. I., Paredes, J. A., Bisonard, E. M., and Rago, A. M. 2016b. Detección y cuantificación de teliosporas de Thecaphora frezii en semillas de maní usando PCR en Tiempo Real. $31^{\circ}$ Jornada Nacional de Maní. 22 de Septiembre. General Cabrera, Córdoba, Argentina.

Cazzola, N., Gateu, M., March, G., Marinelli, A., García, J., Rago, A., and Oddino, C. 2012. Intensidad y pérdidas ocasionadas por carbón del maní según regiones de producción. Pages 34-35 in: $27^{\circ}$ Jornada Nacional del Maní. General Cabrera, Córdoba, Argentina.

Cignetti, M., Baldessari, J., Marraro Acuña, F., and Mazzini, P. 2010a. Evaluación multianual de cultivares de maní frente al carbón (Thecaphora frezii). Pages 20-22 in: $25^{\circ}$ Jornada Nacional del Maní. General Cabrera, Córdoba, Argentina.

Cignetti, M. I., Marraro Acuña, F., and Mazzini, P. H. 2010b. Influencia de la labranza sobre la intensidad del carbón del maní. Pages 12-14 in: $25^{\circ}$ Jornada Nacional del Maní. General Cabrera, Córdoba, Argentina.

Conforto, C., Cazón, I., Fernandez, F., Marinelli, A., Oddino, C., and Rago, A. 2012. Caracterización molecular de la región D1-D2 de la subunidad ribosomal mayor (DNAr 5' LSU) de Thecaphora frezii, agente causal del carbón del maní. Pages 19-20 in: 27 Jornada Nacional de Maní. General Cabrera, Córdoba, Argentina.

Conforto, C., Cazón, I., Fernandez, F., Marinelli, A., Oddino, C., and Rago, A. 2013. Molecular sequence data of Thecaphora frezii affecting peanut crops in Argentina. Eur. J. Plant Pathol. 137:663-666.

Farías, A., Baldessari, J., Marraro, A. F., and Mazzini, P. H. 2011. Evaluación de cultivares de maní alto-oleico frente al carbón (Thecaphora frezzi). Pages 20-22 in: $26^{\circ}$ Jornada Nacional del Maní. General Cabrera, Córdoba, Argentina.

Faustinelli, P. C., Bressano, M., Soave, S. J., Oddino, C., De Blas, F., Soave, J. H., and Buteler, M. I. 2015. Carbón del maní: desarrollo de marcadores moleculares para asistir al mejoramiento genético. Pages $95-96$ in: 30 Jornada Nacional de Maní. General Cabrera, Córdoba, Argentina.

Fávero, A. P. 2004. Cruzabilidade entre espécies silvestres de Arachis visando à introgressão de genes de resistência a doenças no amendoim cultivado. Doctoral dissertation, Universidade de São Paulo, Brazil.

Fernandez, E. M., Giayetto, O., and Cholaky Sobari, L. 2006. Crecimiento y desarrollo. Pages 73-88 in: El cultivo de maní en Córdoba. E. Fernandez and O. Giayetto, eds. Departamento de Imprenta y Publicaciones de la UNRC Córdoba, Argentina.

Fiant, S., Alonso, C., Fontana, T., Spinazzé, C., Costero, D., Agusto, G., Pérez, C., Bonvehi, L., Fuentes, L., and Meriggiola, P. 2013. Caracterización de la producción de maní. Campaña 2012/2013.Pages 24-25 in: 28 Jornada Nacional de Maní. General Cabrera, Córdoba, Argentina.

Fundación Maní Argentino. 2010. Manejo de enfermedades fúngicas del maní. Informe final.

Ganuza, M. R., Pastor, N. A., Folguera, J., Andrés, J., Reynoso, M. M., Rovera, M., and Torres, A. M. 2016. Perspectivas de aplicación de bioformulado de Trichoderma harzianum ITEM 3636 para el control del carbón del maní. 


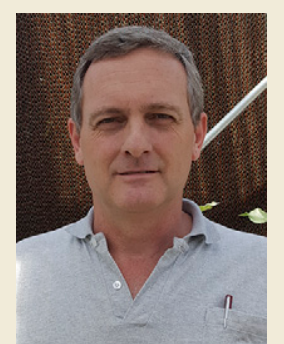

Alejandro Rago

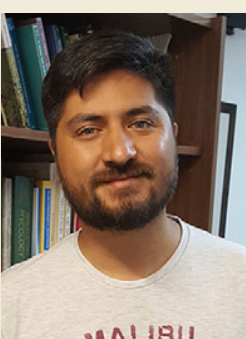

ALIBU

Luis Ignacio Cazón

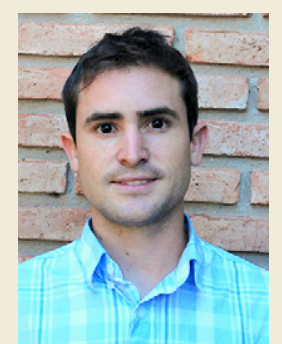

Juan Andrés Paredes

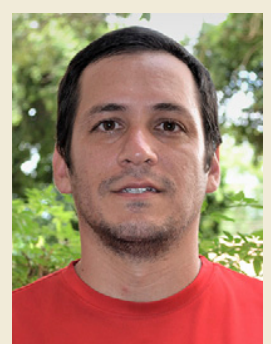

Juan Pablo

Edwards Molina

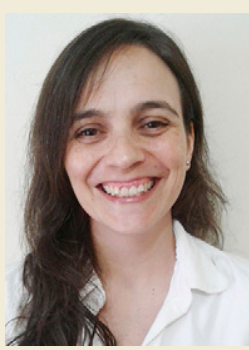

Cinthia Conforto

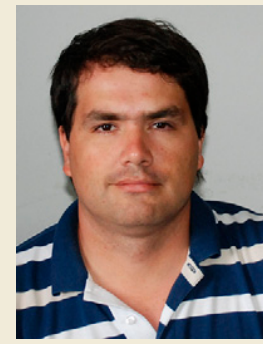

Matías Bisonard

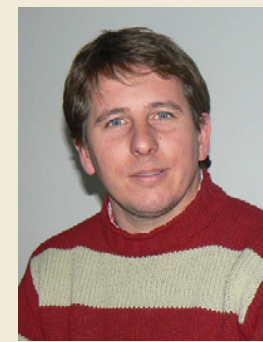

Claudio Oddino
Alejandro Rago is the current chair of the Plant Pathology Institute (IPAVE) of the National Institute of Agricultural Technology (INTA), Argentina. He received his B.Sc. in agronomy in 1992 at the University of Río Cuarto, where he is also professor in the Plant Pathology department. He obtained his M.S. in Plant Pathology at São Paulo University, Brazil. His research focuses on genetic resistance and integrated management of peanut and sugarcane diseases. He coordinated several projects in the National Program of Industrial Crops of INTA.

Ignacio Cazón is a biotechnologist at the Plant Pathology Institute of INTA, Argentina. He obtained his M.S. in seed technology at the University of Córdoba in 2015. He has been working on several peanut fungal diseases since 2011 , focusing his work on molecular characterization and detection of Thecaphora frezii in peanut seeds.

Juan Andrés Paredes is a researcher at the mycology and bacteriology lab of the Plant Pathology Institute of INTA, Argentina, focusing his research on peanut disease management techniques. He obtained his B.S. in agronomy at the University of Córdoba in 2013. His field of research since 2013 is the study of peanut smut management strategies.

Juan $P$. Edwards Molina is a research plant pathologist at the Plant Pathology Institute of INTA, Argentina, and Ph.D. candidate at São Paulo University, Brazil. He obtained his B.S. in agronomy (2007) and M.S. in crop production (2013) from the University of Mar del Plata. His research focuses on describing and modeling plant disease epidemics of field crops and their consequent yield losses. Other topics of his interest are chemical control of fungal disease, including fungicide resistance.

Cinthia Conforto is a plant pathologist researcher for the Plant Pathology Institute of INTA, Argentina. She earned her B.S. in agronomy and M.S. in plant protection at the University of Córdoba. She is currently a Ph.D. candidate at the University of Pernambuco, Brazil, developing studies of etiology and epidemiology of brown spot in small forage palm.

Matías Bisonard is a biologist graduated from the University of Cordoba. In 2009, he began his activities as a researcher working in the epidemiology of Corn Stunt Spiroplasma maize. In 2013, he obtained a research position in the "Fundación Maní Argentino" to work on management strategies of peanut smut. $\mathrm{He}$ is currently pursuing an M.S. degree in agricultural sciences at the University of Río Cuarto, focusing his work on the effect of climate change on the main diseases of soybean, corn, and peanut crops in Argentina.

Claudio Oddino obtained his B.S. in agronomy and M.S. in crop production at the University of Río Cuarto. $\mathrm{He}$ is a professor of plant protection at the same university and several postgraduate programs (University of Río Cuarto, Catholic University of Córdoba, North-West University, and University of Buenos Aires). $\mathrm{He}$ is a plant pathologist at the peanut breeding nursery "El Carmen" in Córdoba, Argentina. He has focused his research on epidemiology and management of peanut and soybean diseases.
Pages 28-30 in: $31^{\circ}$ Jornada Nacional de Maní. 22 de Septiembre. General Cabrera, Córdoba, Argentina.

Kearney, M. I., Cerioni, G. A., Morla, F. D., Bonvilliani, D., Tello, R. D., Avellaneda, M., Díaz Menaches, J., Picco, F., and Segovia, P. 2015. Avances en el control de carbón (Thecaphora frezzii) con la aplicación de fosfitos en el cultivo de maní. Pages 83-84 in: $30^{\circ}$ Jornada Nacional de Maní. General Cabrera, Córdoba, Argentina.

Krapovickas, A., and Gregory, W. C. 1994. Taxonomía del género Arachis (Leguminosae). Bonplandia 8:1-186.

Lavia, G. I. 1998. Karyotypes of Arachis palustris and A. praecox (section Arachis), two species with basic chromosome number $\mathrm{X}=9$. Cytologia (Tokyo) 63:177-181.

March, G., and Marinelli, A. 2005. Enfermedades y sistema productivo. Pages 1-11 in: Enfermedades de maní en Argentina. G. March and A. Marinelli, eds. Biglia Impresores, Córdoba, Argentina.

Marinelli, A., March, G., and Lenardon, S. 2006. Enfermedades del maní. Pages 179-208 in: El cultivo de maní en Córdoba. E. Fernandez and O. Giayetto, eds. Departamento de Imprenta y Publicaciones de la UNRC, Córdoba, Argentina.

Marinelli, A., March, G., and Oddino, C. 2008. Aspectos biológicos y epidemiológicos del carbón del maní (Arachis hypogaea L.) causado por Thecaphora frezii Carranza \& Lindquist. Agriscientia 25:1-5.
Marinelli, A., March, G., Oddino, C., Garcia, J., Rago, A., and Zuza, M. 2010. El carbón del maní de 1995 a 2010 de enfermedad emergente a enfermedad endémica y epidémica. Pages 28-30 in: $25^{\circ}$ Jornada Nacional del Maní. General Cabrera, Córdoba, Argentina.

Marinelli, A., March, G., and Rago, A. 1995. El carbón del maní Thecaphora frezii sobre Arachis hypogaea L. Page 134 in: $7^{\circ}$ Congreso de Micología y $17^{\circ}$ Jornadas Argentinas de Micología. Rosario, Santa $\mathrm{Fe}$, Argentina.

Marraro Acuña, F., Cosa, M., and Wiemer, A. 2013. Carbón del maní: Histología, incidencia y severidad. Pages 26-27 in: $28^{\circ}$ Jornada Nacional de Maní. General Cabrera, Córdoba, Argentina.

Marraro Acuña, F., and Haro, R. J. 2011. Carbón del maní (Thecaphora frezii): su incidencia en rotaciones de cultivo. Pages $28-30$ in: $26^{\circ}$ Jornada Nacional de Maní. General Cabrera, Córdoba, Argentina.

Marraro Acuña, F., Mazzini, P., Morello, L., and Zazzetti, M. 2009. Evaluación de cultivares de maní frente al carbón. Pages 21-22 in: $24^{\circ}$ Jornada Nacional de Maní. General Cabrera, Córdoba, Argentina.

Marraro Acuña, F., Wiemer, A., and Cosa, M. 2012. Carbón del maní bajo la lupa, anatomía de la infección. Pages 52-54 in: $27^{\circ}$ Jornada Nacional del Maní. General Cabrera, Córdoba, Argentina. 
Morla, F., Kearney, M., Cerioni, G., Pichetti, L., Bonvilliani, D., Tello, D., Avellaneda, M., Díaz Menaches, J., Picco, F., and Segovia, P. 2015. Control de viruela de maní (Cercosporidium personatum) combinando fungicidas sistémicos, de contacto y fosfitos. Page 44 in: $15^{\circ}$ Jornadas Fitosanitarias Argentinas. Universidad Nacional del Litoral. Santa Fe, Argentina.

Murashige, T., and Skoog, F. 1962. A revised medium for rapid growth and bio assays with tobacco tissue cultures. Physiologia Plantarum 15:473-497.

O'Donnell, K. L. 1993. Fusarium and its near relatives. Pages 225-233 in: The fungal holomorph: mitotic, meiotic and pleomorphic speciation in fungal systematics. D. R. Reynolds and J. W. Taylor, eds. CAB International, Wallingford, U.K.

Oddino, C., Marinelli, A., March, G., García, J., Tarditi, L., D'Eramo, L. Y., and Ferrari, S. 2010. Relación entre el potencial inóculo de Thecaphora frezii la intensidad de carbón del maní y el rendimiento del cultivo. Pages 24-26 in: $25^{\circ}$ Jornada Nacional del Maní. General Cabrera, Córdoba, Argentina.

Paredes, J. A., Cazón, L. I., Bisonard, E. M., Edwards Molina, J. P., and Rago, A. M. 2015a. Uso de fungicidas para el control de Thecaphora frezii en ensayos a campo. Page 235 in: $15^{\circ}$ Jornadas Fitosanitarias Argentinas. Universidad Nacional del Litoral. Santa Fe, Argentina.

Paredes, J. A., Cazón, L. I., Bisonard, E. M., Oddino, C., and Rago, A. M. 2015b. Efecto de ingredientes activos fungicidas sobre la intensidad del carbón del maní. Pages 68-69 in: 30 Jornada Nacional de Maní. General Cabrera, Córdoba, Argentina.

Paredes, J. A., Cazón, L. I., Bisonard, E. M., and Rago, A. M. 2015c. Efecto de fungicidas con carboxamidas en el control de Thecaphora frezii.Pages 65-66 in: $30^{\circ}$ Jornada Nacional de Maní. General Cabrera, Córdoba, Argentina.
Paredes, J. A., Cazón, L. I., Bisonard, E. M., and Rago, A. M. 2015d. Blanco de aplicación de diferentes fungicidas para el manejo del carbón del maní (Thecaphora frezii). Page 28 in: $15^{\circ}$ Jornadas Fitosanitarias Argentinas. Universidad Nacional del Litoral. Santa Fe, Argentina.

Paredes, J. A., Cazón, L. I., Osella, A., Peralta, V., Alcalde, M., Kearney, M. I., Zuza, M. S., Rago, A. M., and Oddino, C. 2016. Relevamiento regional de carbón del maní y estimación de pérdidas producidas por la enfermedad. Pages 53-54 in: $31^{\circ}$ Jornada Nacional de Maní. 22 de Septiembre. General Cabrera, Córdoba, Argentina.

Paredes, J. A., Edwards Molina, J. P., Cazón, L. I., Bisonard, E. M., and Rago, A. M. 2014. Alternativas tecnologicas de aplicación de fungicidas para el control de Thecaphora frezii. Pages 49-50 in: 29 Jornada Nacional del Maní. General Cabrera, Córdoba, Argentina.

Pastor, N. A., Ganuza, M., Reynoso, M. M., Folguera, J., Rovera, M., and Torres, A. M. 2015. Bioproducto a base de Trichoderma controla el carbón de maní y aumenta de rendimiento del cultivo. Pages 81-82 in: $30^{\circ}$ Jornada Nacional de Maní. General Cabrera, Córdoba, Argentina.

Soave, J., Bianco, C., Burgoa, R., Montaño, R., Rago, A., Cazón, I., Paredes, J. A. Buteler, M., Faustinelli, P., Soave, S., Moresi, A., Torres, D., and Oddino, C. 2014. Primera detección de carbón del maní (Thecaphora frezii) en Bolivia Page 211 in: $3^{\circ}$ Congreso Argentino de Fitopatología. Asociación Argentina de Fitopatólogos, Tucumán, Argentina.

Spinazzé, C., and Marraro Acuña, F. 2010. Estudio del efecto de la ubicación de las esporas sobre la intensidad del carbón del maní. Pages 4-6 in: 30 Jornada Nacional de Maní. General Cabrera, Córdoba, Argentina. 